\title{
Correlates of preferences for autonomy in long-term care: results of a population-based survey among older individuals in Germany
}

This article was published in the following Dove Press journal:

Patient Preference and Adherence

\author{
André Hajek' \\ Thomas Lehnert' \\ Annemarie Wegener' \\ Steffi G Riedel-Heller ${ }^{2}$ \\ Hans-Helmut König' \\ 'Department of Health Economics \\ and Health Services Research, \\ University Medical Center Hamburg- \\ Eppendorf, Hamburg, ${ }^{2}$ Institute of \\ Social Medicine, Occupational Health \\ and Public Health, University of \\ Leipzig, Leipzig, Germany
}

\begin{abstract}
Purpose: Thus far, there is little evidence concerning the factors associated with preferences for autonomy in long-term care. Therefore, the aim of the present study was to investigate the correlates of preferences for autonomy in long-term care among older individuals in Germany.

Methods: Data were gathered from a population-based survey of the German population aged $\geq 65$ years in $2015(\mathrm{~N}=1,006)$.

Results: Multiple logistic regressions revealed that preferences for freedom of choice for foods were positively associated with living with partner or spouse (OR: 1.5 [1.0-2.2]), being born in Germany (OR: 1.9 [1.1-3.3]), and lower self-rated health (OR: 1.3 [1.1-1.6]). Preferences for freedom in choosing bedtime and sleep duration were positively associated with lower age (OR: 1.1 [1.0-1.1]) and having children (OR: 2.2 [1.0-4.9]). Preferences for customized living space were positively associated with being female (OR: 2.5 [1.4-4.5]) and being born in Germany (OR: 3.7 [1.9-7.1]). Neither preferences for decent and sanitary housing nor preferences for shared decision-making were associated with any of the independent variables.

Conclusion: Various independent variables were associated with preferences for autonomy in long-term care. This suggests that preferences for care-related autonomy are complex. Knowing these might help refine long-term care health services.
\end{abstract}

Keywords: caregivers, older adult, long-term care, Germany

\section{Introduction}

For reasons of demographic aging, the number as well as the proportion of elderly individuals is expected to increase substantially in the next years and decades. ${ }^{1}$ As age is positively related to needing long-term care, it is expected that the number of individuals in need of long-term care will increase markedly by $2050 .{ }^{2}$ Usually, individuals have high preferences for living at home, for example, to keep social relations. Furthermore, individuals like to maintain their familiar environment.

Individuals often prefer care settings where they have a high degree of autonomy. ${ }^{3}$ Thus, autonomy is an important factor in long-term care. For example, perceived autonomy is associated with satisfaction of individuals with the services. ${ }^{4,5}$ In addition, it has been found that autonomy was positively associated with increased mental health status among older people in long-term care settings. ${ }^{6}$

Thus far, there is little evidence concerning the factors associated with preferences for autonomy in long-term care. For example, it has been argued that everyday decisionmaking, such as food-related decision-making, is important for the autonomy among individuals residing in nursing home facilities. ${ }^{7}$ However, there is a lack of studies that investigate various factors associated with preferences for autonomy in long-term
Correspondence: André Hajek Department of Health Economics and Health Services Research, University Medical Center Hamburg-Eppendorf, Martinistraße 52, 20246 Hamburg,

Germany

Tel +494074I05 2877

Fax +4940741040261

Email a.hajek@uke.de 
care in a broader sense. Consequently, the aim of this study was to examine correlates of preferences for autonomy in long-term care in older individuals. Data were derived from a population-based survey among individuals aged 65 years and over in Germany, assuming that these individuals are at increased risk of needing long-term care. ${ }^{8,9}$ This is the main reason why we concentrated on individuals in this age bracket. In addition, it has been reported that individuals in this age bracket are more experienced with regard to various factors of long-term care. ${ }^{10}$

Knowing factors related to preferences for autonomy in long-term care is of great importance, for example, for nursing services, policy-makers, caregivers, and care recipients themselves. Particularly, this knowledge might help reduce the discrepancy between long-term care preferences of care recipients and practice. ${ }^{11}$ Reducing this gap might enhance satisfaction of individuals in need of care.

\section{Methods}

\section{Sample}

Older individuals ( $\geq 65$ years; $N=1,006$ ) were interviewed via telephone (computer-assisted telephone interview) for about 25 minutes. USUMA (Unabhängige Serviceeinrichtung für Umfragen, Methoden und Analysen; Berlin; independent service for surveys, methods, and analyses in market and social research), a company specialized in market and social research, conducted the fieldwork in 2015. To obtain a representative sampling, individuals were randomly selected from registered private telephone numbers. For that purpose, the Guidelines for Telephone Surveys (from the ADM Arbeitskreis Deutscher Markt- und Sozialforschungsinstitute e.V.) were used. Furthermore, additional computer-generated numbers allowed for extra-directory households as well. Moreover, repeated calls were made at different times on different days of the week until an answer was obtained. The number was dropped if the telephone was not answered at the tenth attempt. From the gross sample $(\mathrm{N}=2,346), \mathrm{N}=1,006$ interviews were realized (42.9\%). The main reasons for refusal were lack of time/lack of interest (12.1\%) and refusal to take part in telephone surveys (26.5\%). Further details were provided elsewhere. ${ }^{12}$ Prior to assessment, individuals gave their oral informed consent. Based on this cohort, another study was conducted examining the factors associated with preferences of old-age individuals for long-term care settings in Germany. ${ }^{13}$

The study was reviewed and approved by the Ethics Committee of the General Medical Council Hamburg, Germany (approval number PV4781). The ethical guidelines of the International Code of Marketing and Social Research Practise by the International Chamber of Commerce and the European Society for Opinion and Marketing Research were followed.

The questionnaire was developed to measure long-term care preferences. For this purpose, a systematic review of the literature (currently under review) as well as expert interviews ${ }^{3}$ was conducted. The questions were not copied without modification, but rather developed and reformulated using the existing items because Likert scales were not used. Furthermore, they were adapted to the group of old-age individuals.

Pretests including (1) evaluation conversations and (2) a pilot study were conducted to improve the questionnaire. Experts, guided interviews, and telephone interviews with participants not included in our study were also part of the evaluation conversations. Afterward, $\mathrm{N}=31$ individuals (meeting the inclusion criteria) took part in a pretest under field conditions (pilot study). Moreover, a glossary (explaining the items and clarifying the goals) was provided to trained staff from USUMA. Further details were provided elsewhere. ${ }^{14}$

\section{Outcome measures}

Preferences for autonomy in long-term care were measured as follows: Concerning your personal independence: all in all it is very important to me that (ranging from $1=$ "totally agree" to $4=$ "totally disagree"):

(1) ... important care-related decisions are made in consultation with close kin and friends (short: shared decisionmaking)

(2) ... I have freedom of choice for dishes and foods (short: choice for foods)

(3) ... I have freedom in choosing bedtime and sleep duration (short: bedtime and sleep duration)

(4) ... I have decent and sanitary housing (short: decent and sanitary housing)

(5) ... I have a customized living space (short: customized living space)

The five outcomes measured were all recorded as dichotomous variables $(0=$ "totally disagree" and "rather disagree"; 1= "totally agree" and "rather agree") to reflect low preferences versus high preferences. It should be noted that the terms "preferences" and "importance" have been used synonymously in the present study.

\section{Independent variables}

Age in years, gender (female, male), living situation (living with partner or spouse; others [living alone, living with 
other family members, living with other individuals]), education (without a vocational degree; apprenticeship, full-time vocational school; professional school or trade and technical school for vocational education; university, school of engineering), and having children (yes, no) were included as independent variables in our regression models. In addition, the region (West Germany, East Germany) and the place of birth (born in Germany, born abroad) were used. Furthermore, the provision or absence of informal care for family or friends (yes, no) was measured. Moreover, the status of health insurance (statutory health insurance, private health insurance) was used.

In agreement with the German long-term care insurance, the present need of care was assessed by recording the level of care: ${ }^{15}$ To claim benefits from the long-term care insurance, individuals must need a minimum of 1.5 hours of assistance with basic activities of daily living per day. Depending on the extent of care required, recipients were categorized into three levels after an assessment by a nurse/physician of the medical service of the German statutory health insurance system. This variable was dichotomized $(0=$ no level of care; $1=$ levels 1-3). Subjective health was quantified using self-rated health (from $1=$ "very bad" to $5=$ "very good"). Furthermore, the involvement in the issue of need for care (How much have you thought about the issue of "need for care") was measured (from $1=$ "very little" to $5=$ "very much").

\section{Statistical analysis}

First, the two groups (low preferences, high preferences) were compared bivariately using independent $t$-tests and chisquare procedures as appropriate. Second, multiple logistic regressions were used to investigate the factors associated with the five dependent variables (shared decision-making, choice for foods, bedtime and sleep duration, decent and sanitary housing, customized living space). The level of significance was set at $P<0.05$. All statistical analyses were performed using Stata 14 (Stata Corp., College Station, TX, USA).

\section{Results}

\section{Bivariate analysis}

Sample characteristics and bivariate associations are depicted in Table 1. Of the individuals, $96.2 \%$ reported high preferences for shared decision-making, $82.2 \%$ reported high preferences for freedom of choice for foods, $95.8 \%$ reported high preferences for freedom in choosing bedtime and sleep duration, 97.9\% reported high preferences for decent and sanitary housing, and $93.0 \%$ reported high preferences for customized living space.

\section{Regression analysis}

Multiple logistic regressions (Table 2) revealed that preferences for freedom of choice for foods were positively associated with living with partner or spouse (OR: 1.5 [1.0-2.2]), being born in Germany (OR: 1.9 [1.1-3.3]), and lower selfrated health (OR: 1.3 [1.1-1.6]). Preferences for freedom in choosing bedtime and sleep duration were positively associated with lower age (OR: 1.1 [1.0-1.1]) and having children (OR: 2.2 [1.0-4.9]). Preferences for customized living space were positively associated with being female (OR: 2.5 [1.4-4.5]) and being born in Germany (OR: 3.7 [1.9-7.1]). Neither preferences for decent and sanitary housing nor preferences for shared decision-making were associated with any of the independent variables.

We also used a stepwise approach (backward elimination, with $P<0.05$ ) to seek a more parsimonious model (one that is simple but fits almost as well). Table S1 provides further details.

\section{Discussion \\ Relation to previous research}

In this study, we examined the correlates of preferences for autonomy in long-term care among older individuals in Germany through a survey of the German population aged 65 years and over. We found that preferences for freedom of choice for foods were positively associated with living with partner or spouse, being born in Germany, and lower selfrated health. The relation between the outcome measure and the place of birth might be explained by differences in values and expectations between individuals born in Germany and individuals born abroad. Freedom of choice for foods might be seen as a postmaterialist value (eg, freedom of speech or autonomy in certain aspects of life), which would be in accordance with the finding that postmaterialist values in Germany are quite high compared internationally. ${ }^{16}$ Furthermore, the association between the living situation as well as lower self-rated health and the outcome variable might be explained by the fact that older individuals living alone and individuals in bad health might have a stronger focus on needs that are more basic. This would be in accordance with Maslow's hierarchy of needs. ${ }^{17}$

In addition, preferences for freedom in choosing bedtime and sleep duration were positively associated with lower age and having children. The association between lower age and high preferences in this area might be explained by differences in values. More specifically, younger individuals might have greater postmaterialist values than their older counterparts. ${ }^{18}$ The association between childless individuals 
Table I Bivariate associations between preferences for autonomy in long-term care and independent variables

\begin{tabular}{|c|c|c|c|c|c|c|}
\hline \multirow[t]{2}{*}{ Independent variables } & \multicolumn{3}{|c|}{ Shared decision-making } & \multicolumn{3}{|c|}{ Choice for foods } \\
\hline & $\begin{array}{l}\text { Low } \\
\text { preferences } \\
(38 ; 3.8 \%)\end{array}$ & $\begin{array}{l}\text { High } \\
\text { preferences } \\
(960 ; 96.2 \%)\end{array}$ & $P$-value & $\begin{array}{l}\text { Low } \\
\text { preferences } \\
(178 ; 17.8 \%)\end{array}$ & $\begin{array}{l}\text { High } \\
\text { preferences } \\
(820 ; 82.2 \%)\end{array}$ & $P$-value \\
\hline Age: mean (SD) & $76.1(7.4)$ & $75.6(6.6)$ & $P=0.68$ & $75.8(6.5)$ & $75.6(6.6)$ & $P=0.71$ \\
\hline Sex: n (\%) & & & $P=0.64$ & & & $P=0.81$ \\
\hline Male & 15 (3.5\%) & $416(96.5 \%)$ & & $76(17.5 \%)$ & $358(82.5 \%)$ & \\
\hline Female & $23(4.1 \%)$ & $544(95.9 \%)$ & & $102(18.1 \%)$ & $462(81.9 \%)$ & \\
\hline Living situation: n (\%) & & & $P=0.53$ & & & $P<0.05$ \\
\hline Living with partner or spouse & $13(3.3 \%)$ & 377 (96.7\%) & & $56(14.4 \%)$ & $333(85.6 \%)$ & \\
\hline Others & $25(4.1 \%)$ & $583(95.9 \%)$ & & $122(20.0 \%)$ & $487(80.0 \%)$ & \\
\hline Region: n (\%) & & & $P=0.32$ & & & $P=0.38$ \\
\hline East Germany & $7(2.8 \%)$ & $246(97.2 \%)$ & & $4 \mathrm{I}(16.0 \%)$ & $215(84.0 \%)$ & \\
\hline West Germany & $31(4.2 \%)$ & $714(95.8 \%)$ & & 137 (|8.5\%) & $605(81.5 \%)$ & \\
\hline Education: $\mathrm{n}(\%)$ & & & $P=0.25$ & & & $P=0.35$ \\
\hline Without a vocational degree & $2(2.7 \%)$ & $72(97.3 \%)$ & & $13(17.8 \%)$ & $60(82.2 \%)$ & \\
\hline Apprenticeship, full-time vocational school & II (2.9\%) & $368(97.1 \%)$ & & 67 (I7.7\%) & $311(82.3 \%)$ & \\
\hline $\begin{array}{l}\text { Professional school or trade and technical school } \\
\text { for vocational education }\end{array}$ & $8(3.3 \%)$ & $233(96.7 \%)$ & & $52(21.4 \%)$ & 191 (78.6\%) & \\
\hline $\begin{array}{l}\text { University, university of applied sciences, school } \\
\text { of engineering }\end{array}$ & 17 (5.7\%) & $281(94.3 \%)$ & & $46(15.4 \%)$ & $252(84.6 \%)$ & \\
\hline Place of birth: $\mathrm{n}(\%)$ & & & $P=0.95$ & & & $P<0.1$ \\
\hline Born abroad & $3(4.0 \%)$ & $73(96.0 \%)$ & & $19(25.3 \%)$ & $56(74.7 \%)$ & \\
\hline Born in Germany & $35(3.8 \%)$ & $884(96.2 \%)$ & & $159(17.3 \%)$ & $76 I(82.7 \%)$ & \\
\hline Has children: $\mathrm{n}(\%)$ & & & $P<0.01$ & & & $P=0.87$ \\
\hline No & $13(8.0 \%)$ & 149 (92.0\%) & & $30(18.3 \%)$ & $134(81.7 \%)$ & \\
\hline Yes & $25(3.0 \%)$ & $810(97.0 \%)$ & & $148(\mid 7.8 \%)$ & $685(82.2 \%)$ & \\
\hline Status of health insurance: $\mathrm{n}(\%)$ & & & $P<0.0$ I & & & $P=0.74$ \\
\hline Statutory health insurance & $27(3.2 \%)$ & $825(96.8 \%)$ & & $151(17.7 \%)$ & $700(82.3 \%)$ & \\
\hline Private health insurance & II (7.8\%) & 131 (92.2\%) & & $27(18.9 \%)$ & $116(81.1 \%)$ & \\
\hline Provided care for family/friends: $\mathrm{n}$ (\%) & & & $P=0.28$ & & & $P=0.12$ \\
\hline No & $15(3.1 \%)$ & $464(96.9 \%)$ & & $76(15.9 \%)$ & $403(84.1 \%)$ & \\
\hline Yes & $23(4.4 \%)$ & $495(95.6 \%)$ & & $102(19.7 \%)$ & $416(80.3 \%)$ & \\
\hline Level of care: $\mathrm{n}(\%)$ & & & $P=0.40$ & & & $P=0.12$ \\
\hline No & I (I.7\%) & $58(98.3 \%)$ & & $6(10.2 \%)$ & $53(89.8 \%)$ & \\
\hline Yes & $36(3.8 \%)$ & $900(96.2 \%)$ & & $170(18.2 \%)$ & $766(81.8 \%)$ & \\
\hline $\begin{array}{l}\text { Self-rated health (from I= very bad to } 5=\text { very } \\
\text { good): mean (SD) }\end{array}$ & $3.7(1.0)$ & $3.6(0.9)$ & $P=0.82$ & $3.8(0.9)$ & $3.6(0.9)$ & $P<0.05$ \\
\hline $\begin{array}{l}\text { Involvement in the issue of need for care } \\
\text { (from I= very little to } 5=\text { very much): mean (SD) }\end{array}$ & $2.8(1.7)$ & $2.9(1.4)$ & $P=0.82$ & $3.0(1.5)$ & $2.9(1.4)$ & $P=0.22$ \\
\hline
\end{tabular}

Note: Comparisons between the two groups were done using $t$-test and chi-square procedures.

and this outcome measure might also be explained by the fact that being childless is positively associated with being materialistic, which might reflect reduced preferences for freedom in choosing bedtime and sleep duration. For example, it was found that materialistic male are more likely to be childless than nonmaterialistic male. ${ }^{19}$

Preferences for customized living space were positively associated with being female and being born in Germany. The association between being born in Germany and high preferences might be explained by the desire for customized living space among German individuals in international comparison. For example, it has been shown that individualism is high among German students. ${ }^{20}$ This might reflect high preferences for customized living space. Furthermore, it is assumed that female and male have different preferences for customized living space.

We found that neither preferences for decent and sanitary housing nor preferences for shared decision-making were associated with any of the explanatory variables. A possible explanation for these nonsignificant associations might be that almost every individual has high preferences in these areas (shared decision-making: 96.2\%; decent and sanitary housing: 97.9\%). Therefore, these preferences might be generally considered as basic needs. In total, the current study adds new insights into the factors related to various preferences for autonomy (shared decision-making, choice for foods, 


\begin{tabular}{|c|c|c|c|c|c|c|c|c|}
\hline \multicolumn{3}{|c|}{ Bedtime and sleep duration } & \multicolumn{3}{|c|}{ Decent and sanitary housing } & \multicolumn{3}{|c|}{ Customized living space } \\
\hline $\begin{array}{l}\text { Low } \\
\text { preferences } \\
(42 ; 4.2 \%) \\
\end{array}$ & $\begin{array}{l}\text { High } \\
\text { preferences } \\
(954 ; 95.8 \%)\end{array}$ & $P$-value & $\begin{array}{l}\text { Low } \\
\text { preferences } \\
(21 ; 2.1 \%)\end{array}$ & $\begin{array}{l}\text { High } \\
\text { preferences } \\
(982 ; 97.9 \%)\end{array}$ & $P$-value & $\begin{array}{l}\text { Low } \\
\text { preferences } \\
(\mathbf{7 0 ; 7 . 0 \% )}\end{array}$ & $\begin{array}{l}\text { High } \\
\text { preferences } \\
(927 ; 93.0 \%)\end{array}$ & $P$-value \\
\hline \multirow[t]{2}{*}{$77.6(6.6)$} & $75.6(6.6)$ & $P<0.10$ & $75.6(7.7)$ & $75.6(6.6)$ & $P=0.96$ & $76.7(6.9)$ & $75.5(6.6)$ & $P=0.16$ \\
\hline & & $P=0.50$ & & & $P<0.05$ & & & $P<0.01$ \\
\hline $16(3.7 \%)$ & 415 (96.3\%) & & 14 (3.2\%) & $420(96.8 \%)$ & & $43(10.0 \%)$ & 387 (90.0\%) & \\
\hline \multirow[t]{2}{*}{$26(4.6 \%)$} & $539(95.4 \%)$ & & $7(1.2 \%)$ & $562(98.8 \%)$ & & $27(4.8 \%)$ & $540(95.2 \%)$ & \\
\hline & & $P=0.70$ & & & $P=0.71$ & & & $P<0.10$ \\
\hline 15 (3.9\%) & $370(96.1 \%)$ & & $9(2.3 \%)$ & 381 (97.7\%) & & $34(8.7 \%)$ & 355 (91.3\%) & \\
\hline \multirow[t]{2}{*}{$27(4.4 \%)$} & 584 (95.6\%) & & $12(2.0 \%)$ & 601 (98.0\%) & & $36(5.9 \%)$ & $572(94.1 \%)$ & \\
\hline & & $P=0.63$ & & & $P<0.10$ & & & $P=0.36$ \\
\hline $12(4.7 \%)$ & $24 \mathrm{I}(95.3 \%)$ & & $2(0.8 \%)$ & 254 (99.2\%) & & 21 (8.3\%) & $232(91.7 \%)$ & \\
\hline \multirow[t]{2}{*}{$30(4.0 \%)$} & $713(96.0 \%)$ & & $19(2.5 \%)$ & 728 (97.5\%) & & $49(6.6 \%)$ & 695 (93.4\%) & \\
\hline & & $P=1.0$ & & & $P=0.22$ & & & $P=0.70$ \\
\hline $3(4.1 \%)$ & 70 (95.9\%) & & $2(2.7 \%)$ & $72(97.3 \%)$ & & $5(6.8 \%)$ & $69(93.2 \%)$ & \\
\hline $16(4.2 \%)$ & $36 \mid(95.8 \%)$ & & 7 (1.8\%) & 373 (98.2\%) & & 31 (8.2\%) & 347 (91.8\%) & \\
\hline 10 (4.1\%) & 233 (95.9\%) & & $2(0.8 \%)$ & 242 (99.2\%) & & 14 (5.8\%) & $228(94.2 \%)$ & \\
\hline \multirow[t]{2}{*}{12 (4.0\%) } & 285 (96.0\%) & & 10 (3.3\%) & 289 (96.7\%) & & 20 (6.7\%) & 278 (93.3\%) & \\
\hline & & $P=0.95$ & & & $P=0.74$ & & & $P<0.05$ \\
\hline 3 (4.0\%) & 72 (96.0\%) & & 2 (2.6\%) & 74 (97.4\%) & & 10 (I3.2\%) & 66 (86.8\%) & \\
\hline \multirow[t]{2}{*}{$38(4.1 \%)$} & 880 (95.9\%) & & $19(2.1 \%)$ & 905 (97.9\%) & & $60(6.5 \%)$ & 859 (93.5\%) & \\
\hline & & $P<0.10$ & & & $P=0.74$ & & & $P=0.90$ \\
\hline II (6.7\%) & I52 (93.3\%) & & $4(2.4 \%)$ & 160 (97.6\%) & & II (6.8\%) & I5I (93.2\%) & \\
\hline \multirow[t]{2}{*}{30 (3.6\%) } & 802 (96.4\%) & & $17(2.0 \%)$ & 821 (98.0\%) & & 59 (7.1\%) & 775 (92.9\%) & \\
\hline & & $P=0.40$ & & & $P=0.21$ & & & $P=0.48$ \\
\hline 37 (4.3\%) & 814 (95.7\%) & & 16 (1.9\%) & 840 (98.1\%) & & 58 (6.8\%) & 794 (93.2\%) & \\
\hline \multirow[t]{2}{*}{$4(2.8 \%)$} & 137 (97.2\%) & & $5(3.5 \%)$ & 138 (96.5\%) & & $12(8.5 \%)$ & 130 (91.5\%) & \\
\hline & & $P=0.56$ & & & $P=0.19$ & & & $P=0.39$ \\
\hline 22 (4.6\%) & 455 (95.4\%) & & 13 (2.7\%) & 467 (97.3\%) & & 37 (7.8\%) & 440 (92.2\%) & \\
\hline \multirow[t]{2}{*}{20 (3.9\%) } & 498 (96.1\%) & & $8(1.5 \%)$ & 514 (98.5\%) & & 33 (6.4\%) & 486 (93.6\%) & \\
\hline & & $P=0.68$ & & & $P=0.43$ & & & $P=0.56$ \\
\hline $3(5.2 \%)$ & 55 (94.8\%) & & 2 (3.4\%) & 57 (96.6\%) & & 3 (5. I\%) & 56 (94.9\%) & \\
\hline 38 (4.1\%) & 897 (95.9\%) & & 18 (1.9\%) & 923 (98.1\%) & & 66 (7.1\%) & 869 (92.9\%) & \\
\hline $3.7(0.9)$ & $3.6(0.9)$ & $P=0.65$ & $3.7(1.0)$ & $3.6(0.9)$ & $P=0.66$ & $3.5(1.0)$ & $3.6(0.9)$ & $P=0.24$ \\
\hline $2.9(1.5)$ & $2.9(I .4)$ & $P=0.95$ & $2.4(\mathrm{I} .3)$ & $2.9(I .4)$ & $P=0.14$ & $2.6(1.6)$ & $2.9(1.4)$ & $P<0.10$ \\
\hline
\end{tabular}

bedtime and sleep duration, decent and sanitary housing, customized living space) in long-term care.

\section{Strengths and limitations}

A strength of the present study was that data were gathered from a population-based sample in elderly individuals ( $\geq 65$ years). However, a sample selection bias cannot be ruled out. As one of a few studies, the present study adds insights into the correlates of preferences for autonomy in long-term care in a broader sense. The current study is cross-sectional in its design. Further longitudinal studies are thus needed to clarify causal relationships among the factors investigated. As sample selection bias cannot be ruled out, it might be difficult to generalize our findings, for example, for individuals with low education. In addition, it is likely that other factors that are unobserved, such as personality-related factors, are associated with preferences in long-term care ${ }^{21}$ Furthermore, future studies are needed to validate the instruments used.

\section{Conclusion}

Various independent variables were associated with preferences for autonomy in long-term care. This suggests that preferences for care-related autonomy are complex. Knowing these preferences might help to refine long-term care health services. This in turn might help to increase the satisfaction of care recipients with these services. 
Table 2 Predictors of preferences for autonomy in long-term care: results of multiple logistic regressions (for each outcome measure: $0=$ low preferences; I= high preferences)

\begin{tabular}{|c|c|c|c|c|c|}
\hline Independent variables & $\begin{array}{l}\text { Shared } \\
\text { decision-making }\end{array}$ & $\begin{array}{l}\text { Choice for } \\
\text { foods }\end{array}$ & $\begin{array}{l}\text { Bedtime and } \\
\text { sleep duration }\end{array}$ & $\begin{array}{l}\text { Decent and } \\
\text { sanitary housing }\end{array}$ & $\begin{array}{l}\text { Customized } \\
\text { living space }\end{array}$ \\
\hline Age & $0.98(0.93-1.03)$ & $0.98(0.95-1.00)$ & $0.95(0.90-1.00)^{*}$ & $\mathrm{I} .02(0.95-1.09)$ & $0.98(0.94-1.02)$ \\
\hline Sex (Ref: male) & $0.75(0.34-1.64)$ & I.3I (0.88-I.95) & $\mathrm{I} .03(0.47-2.27)$ & $2.17(0.72-6.56)$ & $2.49(1.38-4.50)^{* *}$ \\
\hline $\begin{array}{l}\text { Living situation (Ref: living with partner } \\
\text { or spouse) }\end{array}$ & $1.14(0.54-2.42)$ & $0.67(0.46-0.98)^{*}$ & $0.91(0.43-1.95)$ & $0.94(0.34-2.61)$ & I.II (0.63-I.96) \\
\hline West and East Germany (Ref: East Germany) & $0.57(0.19-1.66)$ & $0.96(0.60-1.53)$ & $1.56(0.69-3.52)$ & $0.19(0.02-1.64)$ & $\mathrm{I} .44(0.76-2.70)$ \\
\hline $\begin{array}{l}\text { Apprenticeship, full-time vocational school } \\
\text { (Ref: without a vocational degree) }\end{array}$ & I.4I (0.37-5.4I) & $1.07(0.55-2.09)$ & $0.75(0.20-2.86)$ & $2.31(0.42-12.79)$ & $0.64(0.22-1.87)$ \\
\hline $\begin{array}{l}\text { Professional school or trade and technical } \\
\text { school for vocational education }\end{array}$ & $0.85(0.22-3.29)$ & $0.80(0.40-1.59)$ & $0.78(0.19-3.25)$ & $10.82(0.66-177.20)^{+}$ & I. $14(0.36-3.64)$ \\
\hline $\begin{array}{l}\text { University, university of applied sciences, } \\
\text { school of engineering }\end{array}$ & $0.85(0.2 I-3.4 I)$ & $\mathrm{I} .22(0.59-2.5 \mathrm{I})$ & $0.76(0.17-3.28)$ & $0.85(0.15-4.66)$ & $1.08(0.35-3.36)$ \\
\hline German born (Ref: no) & $1.48(0.50-4.4 I)$ & $1.92(1.11-3.32)^{*}$ & $1.08(0.31-3.82)$ & $1.42(0.38-5.29)$ & $3.68(1.92-7.07)^{* * *}$ \\
\hline Children (Ref: no children) & $2.05(0.92-4.61)^{+}$ & $0.86(0.53-1.40)$ & $2.22(1.01-4.86)^{*}$ & $1.04(0.31-3.45)$ & $1.27(0.63-2.55)$ \\
\hline $\begin{array}{l}\text { Status of health insurance (Ref: statutory } \\
\text { health insurance) }\end{array}$ & $0.45(0.19-1.06)^{+}$ & $0.80(0.49-I .30)$ & $1.23(0.4 \mathrm{I}-3.66)$ & $0.90(0.32-2.57)$ & $0.92(0.44-1.90)$ \\
\hline Provided care for family/friends (Ref: no) & $0.55(0.26-1.15)$ & $0.86(0.60-1.23)$ & $\mathrm{I} .47(0.7 \mathrm{I}-3.03)$ & I.0I (0.40-2.57) & $0.82(0.48-1.39)$ \\
\hline Level of care (Ref: no) & $0.92(0.20-4.27)$ & $0.62(0.26-1.47)$ & $0.72(0.16-3.31)$ & $2.55(0.45-14.44)$ & $0.56(0.13-2.34)$ \\
\hline $\begin{array}{l}\text { Self-rated health (from I= very bad to } \\
5=\text { very good) }\end{array}$ & $1.38(0.94-2.02)$ & $0.78(0.64-0.95)^{*}$ & $0.98(0.67-1.45)$ & $1.10(0.68-1.79)$ & $1.09(0.82-1.45)$ \\
\hline $\begin{array}{l}\text { Involvement in the issue of need for care } \\
\text { (from I= very little to } 5=\text { very much) }\end{array}$ & I.2I (0.93-I.56) & $0.92(0.81-1.04)$ & $0.95(0.74-1.22)$ & $1.36(0.96-1.92)^{+}$ & $1.20(0.99-1.45)^{+}$ \\
\hline Constant & $\begin{array}{l}\text { II } 5.65 \\
(0.28-48,301.93)\end{array}$ & $\begin{array}{l}143.70 \\
(5.89-3,507.38)^{* *}\end{array}$ & $\begin{array}{l}\mathrm{I}, 105.87 \\
(2.69-454,533.52)^{*}\end{array}$ & $\begin{array}{l}0.50 \\
(0.00-1,178.84)\end{array}$ & $\begin{array}{l}6.56 \\
(0.05-833.79)\end{array}$ \\
\hline Observations & 978 & 978 & 976 & 983 & 978 \\
\hline Pseudo $R^{2}$ & 0.06 & 0.03 & 0.04 & 0.12 & 0.08 \\
\hline
\end{tabular}

Notes: Odds ratios are reported with $95 \%$ confidence intervals in parentheses. ${ }^{+} P<0.10, * P<0.05$, $* * P<0.01$, and $* * * P<0.001$.

Abbreviation: Ref, reference.

\section{Acknowledgments}

This study was funded by the German Federal Ministry of Education and Research (BMBF) (grant: 01EH1101B IIIB). The authors would like to thank all participants for taking the time and effort to participate in the interviews.

\section{Author contributions}

All authors contributed toward the conception and design of the study, acquisition of data, analysis and interpretation of data, drafting the article or revising it critically for important intellectual content, and approved the final version of the manuscript.

\section{Disclosure}

The authors report no conflicts of interest in this work.

\section{References}

1. Kinsella K, Wan H. An Aging World 2008. Washington, DC: U.S. Government Printing Office; 2009.

2. Matthews Z, Channon A, Van Lerberghe W. Will There Be Enough People to Care? Notes on Workforce Implications of Demographic Change 2005-2050. Geneva: World Health Organization; 2006.
3. Heuchert M, König H-H, Lehnert T. Die Rolle von Präferenzen für Langzeitpflege in der sozialen Pflegeversicherung - Ergebnisse von Experteninterviews [The role of preferences in the German long-term care insurance - results from expert interviews]. Gesundheitswesen. Epub 2016 Mar 18. German [with English abstract].

4. Matsui M, Capezuti E. Perveived autonomy and self-care resources among senior center users. Geriatr Nurs. 2008;29(2):141-147.

5. West GE, Quellet D, Quellet S. Resident and staff ratings of foodservices in long-term care: implications for autonomy and quality of life. J Appl Gerontol. 2003;22(1):57-75.

6. Boyle G. The role of autonomy in explaining mental ill-health and depression among older people in long-term care settings. Ageing Soc. 2005;25:731-748.

7. Agich GJ. Actual autonomy and long-term care decision making. In: McCullough LB, Wilson NL, editors. Long-term Care Decisions: Ethical and Conceptual Dimensions. Baltimore, MD: Johns Hopkins University Press; 1995:113-136.

8. Hajek A, Brettschneider C, Ernst A, et al. Einflussfaktoren auf die Pflegebedürftigkeit im Längsschnitt [Longitudinal predictors of the need for care]. Gesundheitswesen. 2017;79(2):73-79. German [with English abstract].

9. Hajek A, Brettschneider C, Lange C, et al. Longitudinal predictors of institutionalization in old age. PLoS One. 2015;10(12):e0144203.

10. Kuhlmey A, Suhr R, Blüher S, Dräger D. Das Risiko der Pflegebedürftigkeit: Pflegeerfahrungen und Vorsorgeverhalten bei Frauen und Männern zwischen 18 und 79 Jahren [The risk of long-term care: nursing experience and preventive care for women and men aged 18 to 79 years]. Gesundheitsmonitor. 2013;5:2013. German [with English abstract]. 
11. Cvengros JA, Christensen AJ, Cunningham C, Hillis SL, Kaboli PJ. Patient preference for and reports of provider behavior: impact of symmetry on patient outcomes. Health Psychol. 2009;28(6):660-667.

12. Hajek A, Lehnert T, Wegener A, Riedel-Heller SG, König H-H. Langzeitpflegepräferenzen der Älteren in Deutschland - Ergebnisse einer bevölkerungsrepräsentativen Umfrage [Long-term care preferences among individuals of advanced age in Germany: results of a population-based study]. Gesundheitswesen. Epub 2017 Mar 7. German [with English abstract].

13. Hajek A, Lehnert T, Wegener A, Riedel-Heller SG, König H-H. Factors associated with preferences for long-term care settings in old age: evidence from a population-based survey in Germany. BMC Health Serv Res. 2017;17(1):156.

14. Hajek A, Lehnert T, Wegener A, Riedel-Heller SG, König H-H. Who should take care of me? Preferences of old age individuals for characteristics of professional long-term caregivers: an observational cross-sectional study. BMC Res Notes. 2017;10(1):382.
15. Rothgang H. Social insurance for long-term care: an evaluation of the German model. Soc Pol Admin. 2010;44(4):436-460.

16. Franzen A. Environmental attitudes in international comparison: an analysis of the ISSP surveys 1993 and 2000. Soc Sci Quart. 2003;84(2): 297-308.

17. Maslow AH. Motivation and Personality. New York, NY: Harper and Row; 1954.

18. Inglehart R. Culture Shift in Advanced Industrial Society. Princeton, NJ: Princeton University Press; 1990.

19. Claxton RP, Murray JB, Janda S. Spouses' materialism: effects of parenthood status, personality type, and sex. J Cons Pol. 1995;18(2-3): 267-291.

20. Darwish A-FE, Huber GL. Individualism vs collectivism in different cultures: a cross-cultural study. Intercult Educ. 2003;14(1):47-56.

21. Sörensen S, Duberstein PR, Chapman B, Lyness JM, Pinquart M. How are personality traits related to preparation for future care needs in older adults? J Gerontol B Psychol Sci Soc Sci. 2008;63(6):P328-P336. 


\section{Supplementary material}

Table SI Predictors of preferences for autonomy in long-term care

\begin{tabular}{|c|c|c|c|c|c|}
\hline Independent variables & $\begin{array}{l}\text { Shared } \\
\text { decision-making }\end{array}$ & Choice for foods & $\begin{array}{l}\text { Bedtime and } \\
\text { sleep duration }\end{array}$ & $\begin{array}{l}\text { Decent and } \\
\text { sanitary housing }\end{array}$ & $\begin{array}{l}\text { Customized } \\
\text { living space }\end{array}$ \\
\hline Age & & & $0.95(0.90-0.99)^{*}$ & & \\
\hline Sex (Ref: male) & & & & $3.12(1.24-7.85)^{*}$ & $2.39(1.45-3.94)^{* * * *}$ \\
\hline $\begin{array}{l}\text { Living situation (Ref: living with } \\
\text { partner or spouse) }\end{array}$ & & $0.70(0.50-0.98)^{*}$ & & & \\
\hline German born (Ref: no) & & $1.87(1.10-3.17)^{*}$ & & & $3.67(1.99-6.76)^{* * * *}$ \\
\hline Children (Ref: no children) & & & $2.18 *(1.02-4.64)$ & & \\
\hline $\begin{array}{l}\text { Status of health insurance } \\
\text { (Ref: statutory health insurance) }\end{array}$ & $0.44(0.21-0.90)^{*}$ & & & & \\
\hline $\begin{array}{l}\text { Self-rated health (from I= very } \\
\text { bad to } 5=\text { very good) }\end{array}$ & & $0.78(0.65-0.94)^{* *}$ & & & \\
\hline Constant & $\begin{array}{l}71.60 \\
(26.38-194.34)^{* * *}\end{array}$ & $\begin{array}{l}8.14 \\
(3.43-19.33)^{* * *}\end{array}$ & $\begin{array}{l}800.02 \\
(20.38-31,406.36)^{* * *}\end{array}$ & $\begin{array}{l}8.69 \\
(2.41-31.32)^{* * *}\end{array}$ & $1.14(0.47-2.77)$ \\
\hline Observations & 978 & 978 & 976 & 983 & 978 \\
\hline Pseudo $R^{2}$ & 0.01 & 0.02 & 0.03 & 0.03 & 0.05 \\
\hline
\end{tabular}

Notes: Results of multiple logistic regressions (for each outcome measure: $0=$ low preferences; $I=$ high preferences) (using backward elimination, with $P<0.05$ ). Odds ratios are reported with $95 \%$ confidence intervals in parentheses. $* P<0.05$, $* * P<0.01$, and $* * * P<0.001$.

Abbreviation: Ref, reference.

\section{Publish your work in this journal}

Patient Preference and Adherence is an international, peer-reviewed, open access journal that focuses on the growing importance of patient preference and adherence throughout the therapeutic continuum. Patient satisfaction, acceptability, quality of life, compliance, persistence and their role in developing new therapeutic modalities and compounds to optimize clinical outcomes for existing disease states are major areas of interest for the journal. This journal has been accepted for indexing on PubMed Central. The manuscript management system is completely online and includes a very quick and fair peer-review system, which is all easy to use. Visit http://www dovepress.com/testimonials.php to read real quotes from published authors. 